\title{
T 字形ダイアフラムで内部補強された角形 CFT 柱梁接合部の局部引張抵抗 STRENGTH OF CFT CONNECTIONS STIFFENED BY T-SHAPED INTERIOR DIAPHRAGMS
}

\author{
菅野良一*，清 水信 孝**，志村 保 美***，島 崎 尚 武****，市之瀬 敏勝***** \\ Ryoichi KANNO, Nobutaka SHIMIZU, Yasumi SHIMURA, \\ Hisatake SHIMAZAKI and Toshikatsu ICHINOSE
}

\begin{abstract}
Concrete filled tubular (CFT) frames have been widely applied in high-rise buildings since the early 1990s. However, there is a need to seek more cost-effective connection details, and this is especially true for square tubes. To meet this need, a relatively simple and cost-saving solution, in which a connection is stiffened with two interior T-shaped diaphragms, was experimentally investigated. This connection detail has been long used for steel frames; however, its application to the CFT frames has been limited because of the lack of information on the behavior and design guidelines. Based on the test results and observations obtained through this research, strength models and design formulas were derived using a limit analysis technique. Comparison with the test results showed that the proposed formulas provided accurate strength estimates.
\end{abstract}

Keywords : CFT frames, beam-column connections, interior diaphragm, local strength, strength models CFT架構、柱梁接合部、内ダイアフラム、局部耐力、耐力モデル

\section{1.はじめに}

設計・施工法や技術審査体制の整備に伴って，コンクリート充填鋼 管（CFT）構造の適用は1990年代初めより急速にその数を增して来 ている. 多くは大スパンが要求される事務所建築への適用であるが, 高層建築の一つの構造形式として確固たる地位を獲得している．この ような急速な普及は，CFT構造の持つ優れた経済性と構造特性に依る ところが大きいが，コンクリートの充填性を確保しながら鉄骨梁と閉 鎖状鋼管柱との強固な接合を同時に満足するというCFT構造固有の課 題も未だ残されている.このためCFT構造の柱梁接合部については継 続的な研究開発が行われて来ており, 通しダイアフラム, 外ダイアフ ラム, 内ダイアフラム以外にも，増厚鋼管，長締めボルトや特殊金物 による形式などの複数の接合部ディテールが提案されている1).

CFT構造には円形鋼管柱と角形鋼管柱の両方が適用されるが，仕上 げの容易さや断面サイズの小ささから角形鋼管の適用が全体の7割程 度を占める．鋼管柱の形状により採用される接合部ディテールも異なつ ており，円形鋼管柱では外リングを部分溶け込み溶接で接合する比較 的簡易なディテールが一般的であるが，角形鋼管については通しダイ アフラムや内ダイアフラムなどの相当量の加工を伴う仕様が採用され ている．通しダイアフラムを例にとれば明らかなように，鋼管の切断 や多くの突き合わせ溶接が必要となるため，柱梁接合ディテールの簡
略化, 低コスト化は角形CFTにおける重要な課題の一つとなっている. 特に最近の溶接仕口部での食い違い・ずれに関わる品質管理強化 ${ }^{2)} の$ 流れも相まって, 合理的な接合ディテールを求めるニーズはより一層 高まっている.

このような中にあって, 主として鉄骨構造の柱梁接合部として実際 に適用されて来ている合理的かつ経済的なディテールがある. この柱 梁接合部は，図1に示すように角形鋼管の内部を 2 組を基本単位とした T字形ダイアフラムで内部補強したものである，一般にスプリットダ

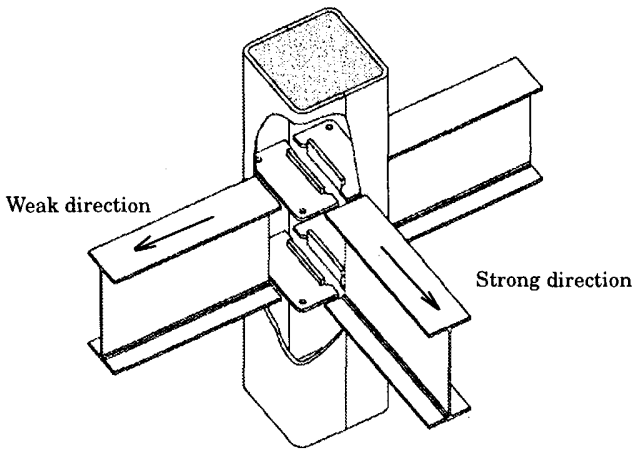

図1Ｔ字形ダイアフラムで内部補強された柱梁接合部

\footnotetext{
* 新日本製鐵銅構造研究開発センター 主幹研究員·Ph. D.

***新日本製鐵鋼構造研究開発セン夕一 研究員・工修

*** 新日本製鐵建材開発技術部 マネジャー・工修

**** ニッテッコラム 部長代理

******名古屋工業大学建築・デザイン工学科 教授・工博
}

Chief Research Engineer, Steel Structure Development Center, Nippon Steel Corp., Ph. D.

Research Engineer, Steel Structure Development Center, Nippon Steel Corp., M. Eng.

Manager, Construction \& Architectural Materials Develop. Div., Nippon Steel Corp., M. Eng.

Maneger, Nittetsu Column Co., Ltd.

Prof., Department of Architecture, Nagoya Institute of Tech., Dr. Eng. 
イアフラム形式と呼ばれており ${ }^{1)}$, 内ダイアフラム形式の一種に分類 される. この接合部ディテールの大きな特徴は, 角形鋼管の製造段階 でダイアフラムの取り付けができる点であり，ファブリケートレスで 角形鋼管へのダイアフラム内藏を実現できる. 図2の製造概要に示す ように，まずプレス成形された溝形鋼の内側に複数のT字形ダイアフ ラムを取り付け，そののち溝形鋼のフランジを相互に溶接接合して構 成する. 図 2 から容易に理解できるように, 冷間プレス成形角形鋼管 の製造ラインにダイアフラム取り付けプロセスを付加することにより 実機化可能であり, 鋼管の切断無しに, 品質・コスト両面で優れた接 合部を実現できる. なお, 図1，2に示されるように, 2組のT字形ダイ アフラムは相互に一定の距離を隔てて開口を形成しながら接合される ため, 所定の開口率と空気拔き孔を確保することによって, コンクリー 卜充填施工上問題なくCFT構造にも適用することが可能である3 ${ }^{3)}$.

このような特徵を持つディテールではあるものの, CFT構造として の力学挙動・特性, 設計法に関する技術的知見は少なく4), 結果とし てCFT構造への適用は限定されている。一部にCFT構造に適用された 例があるものの, 充填コンクリートの存在を無視して設計されている のが一般である. 一方, 図1，2から分かるように，この接合部ディテー ルには弱軸, 強軸といった異方性があり, 加えて弱軸方向に引張力を 受ける場合には, T字形ダイアフラムが充填コンクリート中にアンカー される形態となるためコンクリートとの複雑な合成効果が予測される. この種のコンクリートへのアンカー効果に関するCFT接合部での研究

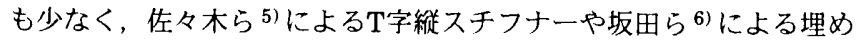
込みアンカーボルトの研究に見られる程度である.したがって，その 接合部特性についてはさらなる調査・検討が必要である.

そこで本研究では, 仕口引張試験によって図1に示す接合部ディテー ルが引張力を受ける場合の力学挙動・特性を実験的に調査するととも に，その知見に基づいて接合部設計法の提案を試みた．ここで対象と するのは梁フランジからの作用力を接合部パネルに伝達する接合部局 部である. なお, 仕口引張試験は接合部局部の力学挙動・特性を調査 する方法 101なととして一般的であるが，逆対称荷重や非対称荷重を受 ける実際の構造骨組における接合部の応力状態をそのまま再現できる ものではないため, この調査に向けては別途検討が必要である.

\section{2. 実験計画の概要}

CFT構造の接合部局部については，鋼管内に充填されたコンクリー トの存在により圧縮力よりも引張力に対する特性が設計上クリティカ

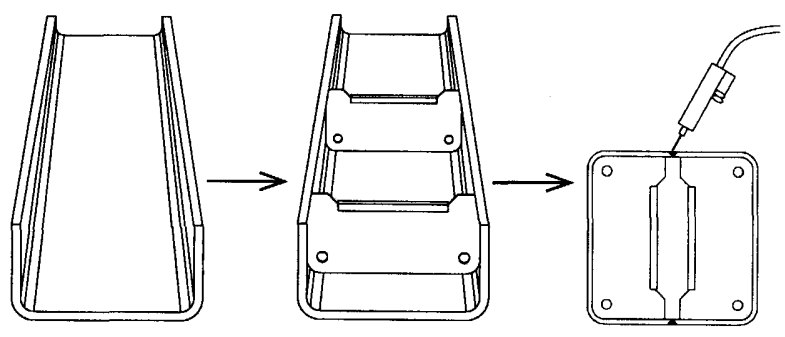

図2ダイアフラム取り付けと鋼管製造の概要

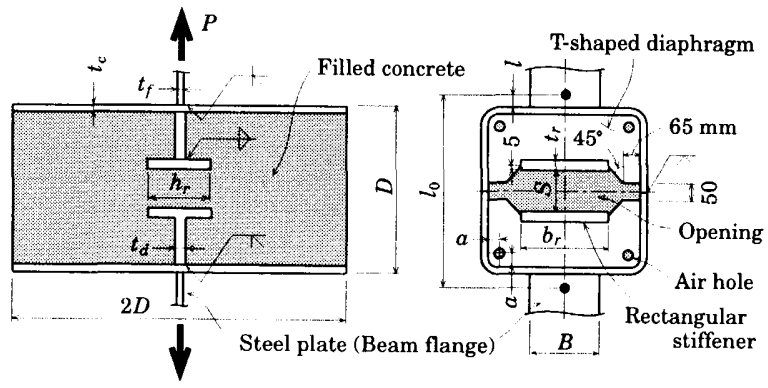

(a) 弱軸方向試験体

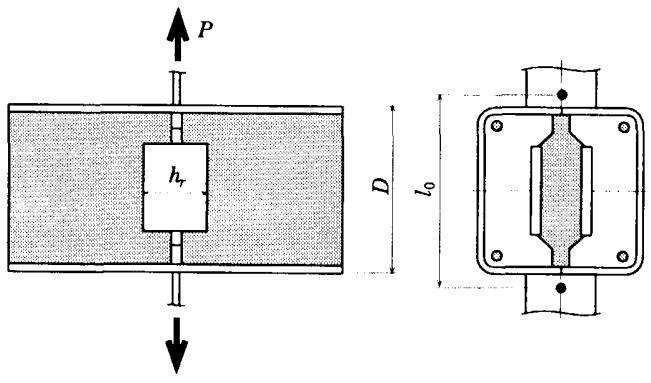

(b) 強軸方向試験体

図3 仕口引張試験体の概要

ルとなる.このため本研究では, 単純な仕口引張試験によって基本的 な力学特性の調査を行った。なお，柱軸方向には作用力を与えていな いため, 本試験における接合部局部の挙動は, 柱軸力がゼロの場合に 対応するものとなる. 既に述べたように，対象とする接合部ディテー ルでは弱軸と強軸が存在するため, 弱軸特性の解明に焦点をおきなが ら強軸の特性についても併せて調査した．図3に弱軸，強軸の仕口引 張試験体の概要を示す．角形鋼管に溶接された鋼板に引張力を作用さ せて試験を行った。ここで，鋼管に溶接された鋼板は実際の柱梁接合

表1 仕口引張試験の試験計画概要

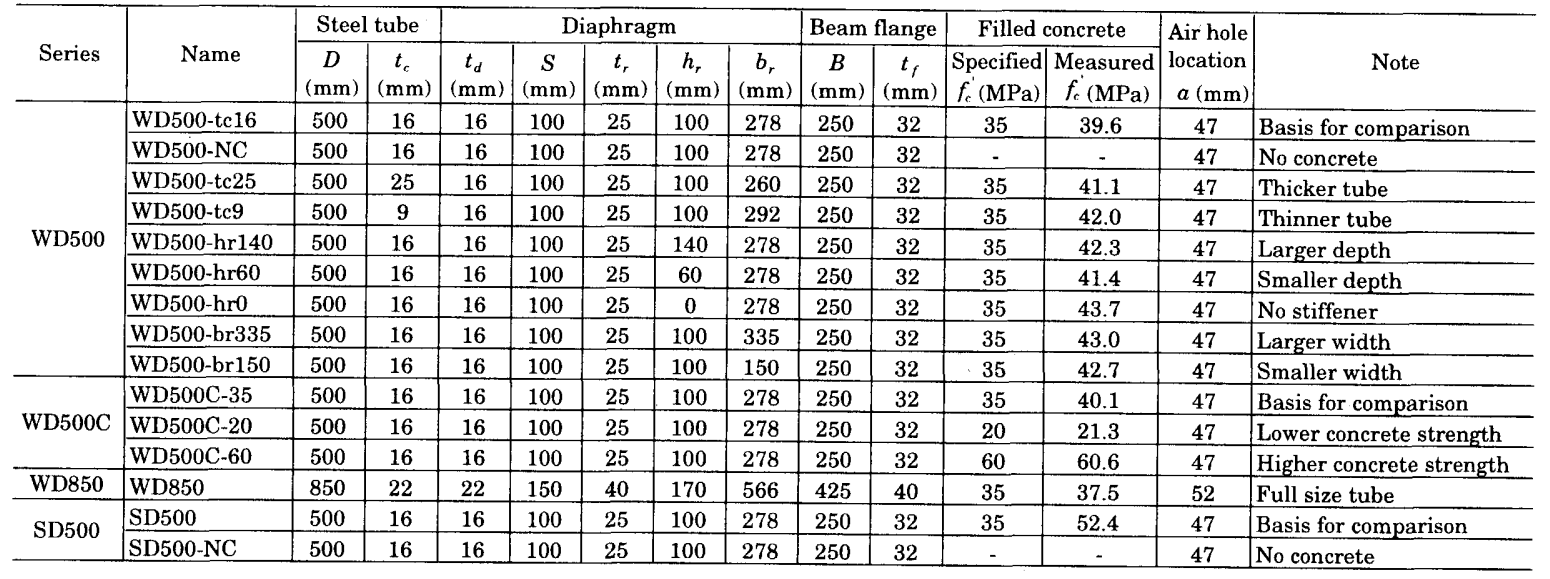


表2 鋼材の機械的特性

\begin{tabular}{|c|c|c|c|c|c|c|}
\hline \multirow{2}{*}{ Series } & \multirow{2}{*}{ Location } & \multicolumn{2}{|c|}{ Thickness (mm) } & \multirow{2}{*}{$\begin{array}{c}\text { Yield strength } \\
\left(\mathrm{N} / \mathrm{mm}^{2}\right)\end{array}$} & \multirow{2}{*}{$\begin{array}{c}\text { Ultimate strength } \\
\left(\mathrm{N} / \mathrm{mm}^{2}\right)\end{array}$} & \multirow{2}{*}{$\begin{array}{c}\text { Elongation } \\
(\%)\end{array}$} \\
\hline & & \begin{tabular}{|l|} 
Nominal \\
\end{tabular} & Measured & & & \\
\hline \multirow{6}{*}{ WD500 } & \multirow{3}{*}{ Steel tube } & 9 & \begin{tabular}{|l|}
9.2 \\
\end{tabular} & 372 & 536 & 24 \\
\hline & & 16 & 16.1 & 356 & 527 & 26 \\
\hline & & 25 & 25.0 & 347 & 525 & 29 \\
\hline & Diaphragm & 16 & 16.5 & 346 & 528 & 27 \\
\hline & Stiffener & 25 & 25.4 & 343 & 517 & 29 \\
\hline & Beam flange & 32 & 32.6 & 521 & 676 & 22 \\
\hline \multirow{4}{*}{ WD500C } & Steel tube & 16 & 16.0 & 344 & 514 & 28 \\
\hline & Diaphragm & 16 & 16.5 & 341 & 520 & 26 \\
\hline & Stiffener & 25 & 25.4 & 328 & 524 & 29 \\
\hline & Beam flange & 32 & 32.7 & 506 & 682 & 23 \\
\hline \multirow{4}{*}{ WD850 } & Steel tube & 22 & 22.1 & 334 & 522 & 29 \\
\hline & Diaphragm & 22 & 22.4 & 347 & 522 & 30 \\
\hline & Stiffener & 40 & 40.4 & 337 & 537 & 36 \\
\hline & Beam flange & 40 & 40.3 & 499 & 692 & 29 \\
\hline \multirow{4}{*}{ SD500 } & Steel tube & 16 & 16.1 & 356 & 527 & 26 \\
\hline & Diaphragm & 16 & 16.5 & 346 & 528 & 27 \\
\hline & Stiffener & 25 & 25.4 & 343 & 517 & 29 \\
\hline & Beam flange & 32 & 32.8 & 508 & 678 & 23 \\
\hline
\end{tabular}

Note: Gauge length for determining the elongation is $50 \mathrm{~mm}$.

部では梁フランジに対応する，試験体に使用した鋼管は冷間プレス成 形角形鋼管であり，ダイアフラムの端部（鋼管中央側）には鋼管径よ りも幅の狭い長方形のスチフナーを溶接接合している. このスチフナー はダイアフラムの曲げ抵抗を高めるためのものであり, 長方形スチフ ナーの存在によりダイアフラムの断面はおおよそT字形状となる.ダ イアフラムには鋼管のコーナー部近傍に径 $32 \mathrm{~mm}$ の空気抜きれを設 けており，実際のディテールとの整合を図るように配慮した．なお， 接合部局部の挙動を終局状態まで調査することを意図し, 接合部より も先行して梁が降伏・破壊することを回避するべく，鋼管に溶接した 鋼板には高強度鋼を使用すると共に，応力集中を避けるために鋼板端 部に半径10 mmで機械仕上げを行った。

接合部の強度特性に影響を及ぼす実験変数として，1）接合部の方 向（弱軸, 強軸），2）充填コンクリートの有無，3）角形鋼管の板厚 $\left.\left(t_{c}\right), 4\right)$ ダイアフラムに接合された長方形スチフナーの幅と深さ $\left.\left(b_{r}, h_{r}\right) ， 5\right)$ コンクリートの一軸圧縮強度 $\left.\left(f_{c}^{\prime}\right) ， 6\right)$ 角形鋼管 の外形寸法 $(D)$ を考慮して実験計画を行った. 計画した試験体の概 要を実験変数の組み合わせも含めて表1に示す．合計で15体の仕口引 張試験を計画しており，そのうち13体が弱軸方向の試験体である．表 1に示すように試験体はWD500，WD500C，WD850，SD500の4つ のシリーズに大別できる.SD500シリーズを除く全ての試験体は弱軸 方向試験体であり，一体のフルサイズ試験体WD850を除いておおよ そ実物比 $60 \%$ 程度の縮小試験体とした．弱軸方向では充填コンクリー ト内にT字形ダイアフラムがアンカーされ，加えて鋼管そのものも作 用する引張力に対して抵抗するため, WD500シリーズではダイアフ ラムに溶接したスチフナーの幅 $\left(b_{r}\right)$ と深さ $\left(h_{r}\right)$ ，鋼管の板厚 $\left(t_{\mathrm{c}}\right)$ を変化させて影響を調查した. WD500Cシリーズはコンクリー 卜強度（ $f_{c}^{\prime} ）$ が及ぼす弱軸方向特性へ影響を調査したケースであり， $35 \mathrm{~N} / \mathrm{mm}^{2}$ を標準強度として 20 から $60 \mathrm{~N} / \mathrm{mm}^{2}$ の範囲で $f_{\mathrm{c}}^{\prime}$ を変化させた. 試験体WD850は弱軸方向特性に及ぼす寸法効果の有無を明らかにす るための実大試験体である. SD500シリーズは強軸方向試験体であり， 強軸方向の特性と充填コンクリート有無の影響の明確化を狙ったもの である．実測したコンクリート強度と鋼材の機械的性質を各々表 1 , 2に示す，なお，コンクリートは空中養生とした．試験では，準静的 な引張力を単調増加で作用させながら荷重と鋼板間の変形を測定した. 図3のように変形測定は鋼管表面から距離 $l$ (WD850シリーズでは $l$
$=50 \mathrm{~mm}$, それ以外では $l=35 \mathrm{~mm}$ ）を隔てた点で規定される標点 距離 $l_{0}(=D+2 l)$ 間で行った. なお, 空気抜き孔の位置は試験体 サイズによって異なるため, 表1中に設置位置（図3中の $a$ ）を示す.

\section{3. 実験結果の概要}

全ての試験体の荷重とのび変形の関係 $(P-\delta)$ を実験変数の影響 が分かるような形で図4に示す．変数の影響が理解できるように，重 複して荷重一変位関係が示されているケースもある. いずれの試験体 でも，載荷初期で明確な線形域を示し，その後徐々に降伏しながら荷 重抵抗を增していく（加工硬化）傾向を示した，最大耐力はいずれの ケースでも鋼材の破壊によって決定されており，弱軸方向試験体では 梁フランジに相当する鋼板の端部から，強軸方向ではダイアフラムに 溶接されたスチフナー端部から発生した. 図5には載荷終了後の典型 的な鋼管の変形状態とフランジ端部からの破壊状況を示す. フランジ 鋼板が取り付く鋼管部分には, 引張力の作用による面外変形の発生が 確認できる. 表3には, 全試験体の性能を表す指標として初期剛性 $K_{0}^{e}$, 降伏耐力 $P_{y 0.2}^{e}$, 終局（ultimate）耐力 $P_{u 5}^{e}$, 最大耐力 $P_{\text {max }}^{e}$ を示す. 各指標を图6に定義する. 初期剛性は初期接線剛性で定めており，降 伏耐力之終局耐力は, 変形 $\delta$ を鋼管径 $D$ で除したひずみ值を基本と して, 降伏耐力 $P_{y 0.2}^{e}$ は $0.2 \%$ off-set荷重により, 終局耐力は $P_{u 5}^{e}$ は $5 \%$ ひずみ時の荷重により与えた。降伏耐力と終局耐力の設定には損傷の 程度を直接考虑すべきとの判断から，このような定義を導入したもの であるが， $0.2 \%$ off-set，5\%ひずみの值自体には明確な根拠は無い. 典型的な例として, 梁せいが鋼管柱径の 1.5 倍の骨組を対象に, 梁に モーメントが作用した際に圧縮側フランジでは接合部局部の変形は生 じない，引張側フランジでは鋼管柱径の $1 / 2$ に相当する接合部局部の 変形が生じるとし, 接合部局部の変形のみを考慮（柱・梁・パネルの 変形は無視）して骨組変形を求めると， $P_{y 0.2}^{e}$ は残留変形が層間変形 角で $1 / 1500$ 程度, $P_{u 5}^{e}$ は最大変形が層間変形角 $1 / 60$ 程度となり, それ ほど的を外した定義ではないことが分かる．図4中の○と $\triangle$ 印が，お のおの $P_{y 0.2}^{e}$ と $P_{u 5}^{e}$ に対応している. なお；ひずみ值が5\%に達する以 前に最大耐力 $P_{\text {max }}^{e}$ に到達した試験体もあったが,この場合には $P_{u 5}^{e}=P_{\max }^{e}$ とした.

図4と表3より，以下のような実験変数による影響が観察された。

(1) 充填コンクリートの有無（図4a，4f）：充填コンクリートの存在 は，接合部弱軸方向の降伏耐力と終局耐力を顕著に向上させる効 果を持つものの, 接合部強軸方向での耐力向上効果は比較的小さ い. 弱軸方向でのこれら耐力向上効果は, 後述する充填コンクリー トの破壊性状で示されるように，T字形ダイアフラムのコンクリー ト中へのアンカー効果によるものである. 強軸方向の耐力上昇は アンカ一効果に起因するものではなく, 鋼とコンクリートの付着 とコンクリートによる鋼管の変形拘束によると考えられる.

（2）鋼管の板厚（図 $4 \mathrm{~b} ） ：$ 鋼管厚 $t_{c}$ は実験変数の中で最も影響度が大 きく，接合部弱軸方向の耐力に顕著な影響をもたらす．図4bから 分かるように, 板厚の増大と共に降伏耐力, 終局耐力共に上昇す る傾向を持つ. 図5で観察された鋼管面の変形性状より, 鋼管厚の 影響は鋼管面の面外曲げ抵抗によって発揮されることが理解でき る. 今回の実験では，鋼管厚の効果は接合部弱軸方向だけで調査 しているが，強軸方向でも同様な効果の発揮が予想される. なお, 図 $4 \mathrm{~b} よ り$ 鋼管厚の増大に伴って最大耐力発揮時の変形が小さくな 


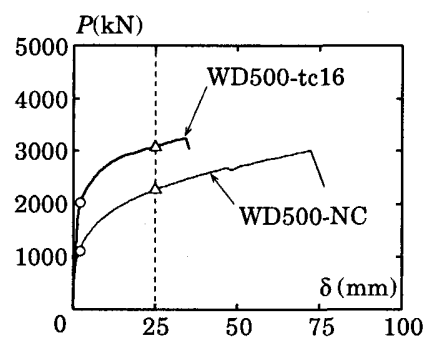

(a) コンクリート有無 (弱軸)

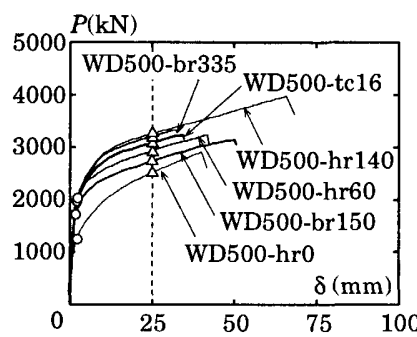

(c) スチフナーのサイズ (弱軸)

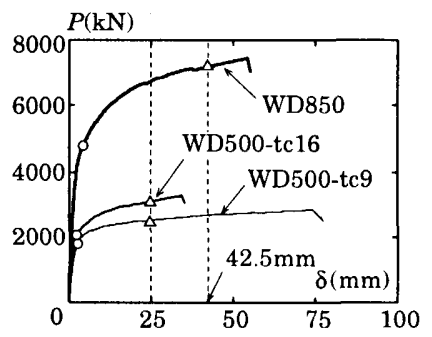

(e) 鋼管径（弱軸）

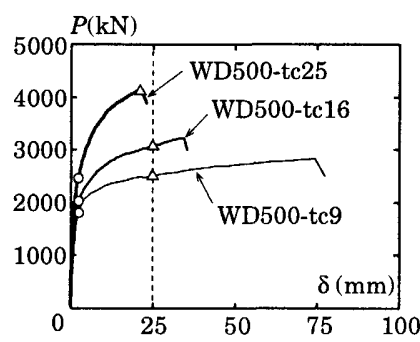

(b) 鋼管の板厚（弱軸）

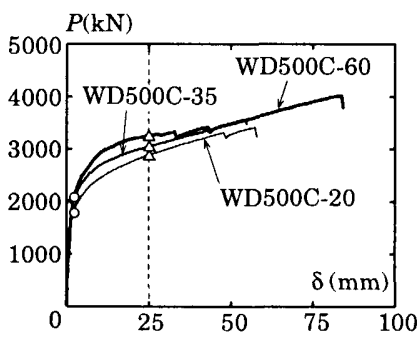

(d) コンクリート強度 (弱軸)

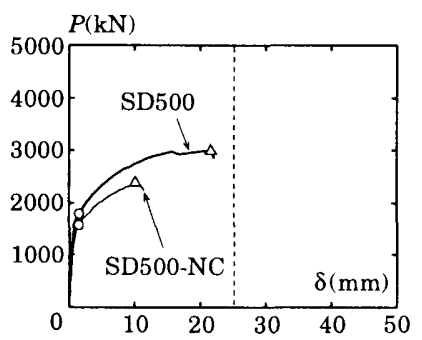

(f) コンクリート有無 (強軸)

図4 荷重一变位関係と実験変数の影響

る傾向がある，既に述べたように，最大耐力はフランジ端部での 鋼管の破壊によって支配されているため，板厚增大に伴う最大耐 力時変形量の隇少はフランジ端部での 3 軸拘束度の增大に起因する ものと考えられる.

(3) ダイアフラムのスチフナー寸法（図4c）：スチフナー無しの試験 体（WD500-hr0）の結果と比較すると，スチフナーの存在により 弱軸方向の降伏耐力と終局耐力が顕著に增大する傾向が確認でき る. 後述する破壊モードから明らかなように，スチフナーによる 耐力上昇はT字形ダイアフラムの充填コンクリートへのアンカー 効果に起因するものである．なお，スチフナーの幅 $b_{r}$ と深さ $h_{r}$ を種々変化させた結果の比較から（図4c），スチフナ一寸法の変 化は終局耐力には影響を及ぼすものの，降伏耐力への影響は小さ いことが分かる、この結果は降伏耐力の向上に有効なスチフナー 寸法には上限があることを示している。

（4）コンクリート強度（図 $4 \mathrm{~d} ） ：$ 実験を行った $20 \sim 60 \mathrm{~N} / \mathrm{mm}^{2}$ の範囲 内では, コンクリート強度の上昇と共に弱軸方向の終局耐力は増 大するものの, 降伏耐力に対しての影響は比較的小さいことが分 かった，なお，図4d糸ら変形量の増大と共にコンクリート強度の 違いによる接合部の強度差が小さくなる傾向にある．他の実験変 数である充填コンクリートの有無やスチフナー寸法による影響度 と比較してコンクリート強度の影響の程度は小さい傾向にあった. なお，今回の実験では鉄筋コンクリート部材で見られるようなコ ンクリート強度の増大に伴う変形能力の低下は観察されなかった.

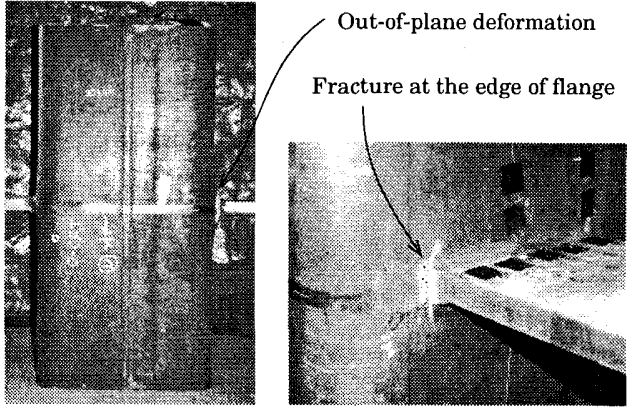

図5＼cjkstart観察された変形と破壊性状

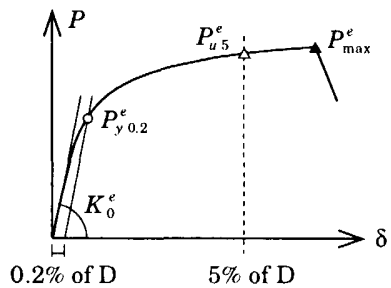

図6 性能指標の定義

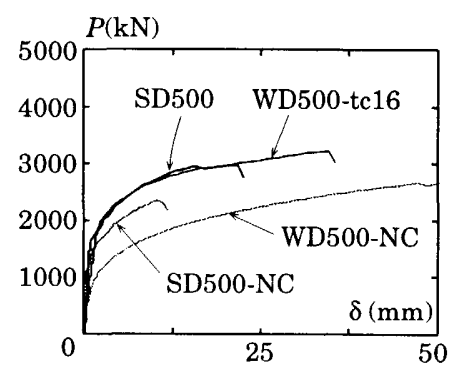

図7弱軸之強軸の差
表3 各試験体の性能指標值

\begin{tabular}{|c|c|c|c|c|c|}
\hline Series & Name & $\begin{array}{c}\text { Initial } \\
\text { stiffness } \\
K_{n}^{*} \\
(\mathrm{kN} / \mathrm{mm}) \\
\end{array}$ & $\begin{array}{c}\text { Yield } \\
\text { strength } \\
P_{y}^{*} 10.2 \\
(\mathrm{kN}) \\
\end{array}$ & $\begin{array}{c}\text { Ultimate } \\
\text { strength } \\
P_{u 5}^{\prime \prime} \\
(\mathrm{kN})\end{array}$ & $\begin{array}{c}\text { Maximum } \\
\text { strength } \\
P_{\operatorname{mix}}^{*} \\
(\mathrm{kN}) \\
\end{array}$ \\
\hline \multirow{9}{*}{ WD500 } & WD500-tc16 & 1442 & \begin{tabular}{|l|}
2032 \\
\end{tabular} & 3079 & 3238 \\
\hline & WD500-NC & 1021 & 1127 & 2271 & 3016 \\
\hline & WD500-tc25 & 1634 & 2460 & 4147 & 4147 \\
\hline & WD500-tc9 & 1345 & 1815 & 2501 & 2832 \\
\hline & WD500-hr140 & 1728 & 2049 & 3268 & 3969 \\
\hline & WD500-hr60 & 1423 & 1972 & 2924 & 3234 \\
\hline & WD500-hr0 & 1400 & 1256 & 2513 & 2916 \\
\hline & WD500-br335 & 1574 & 2040 & 3203 & 3333 \\
\hline & WD500-br150 & 1397 & 1737 & 2744 & 3155 \\
\hline \multirow{3}{*}{ WD500C } & WD500C-35 & 1466 & 2036 & 3051 & 3544 \\
\hline & WD500C-20 & 1399 & 1792 & 2881 & 3413 \\
\hline & WD500C-60 & 1470 & 2068 & 3246 & 4006 \\
\hline WD850 & WD850 & 1772 & 4788 & 7186 & 7433 \\
\hline \multirow{2}{*}{ SD500 } & SD500 & 3134 & 1801 & 3010 & 3010 \\
\hline & SD500-NC & 3016 & 1580 & 2378 & 2378 \\
\hline
\end{tabular}

（5）接合部の方向（図4a，4f）：弱軸と強軸の荷重・変形特性（図4a と図4f）を比較すると，全体的な挙動には大きな違いは無い。唯 一の相違点は, 強軸では最大耐力発揮時の変形量がより小さい傾 向にあることであり，強軸の終局状態がダイアフラムからの破壊 によって決定されていることに起因する，ダイアフラムの破壊状 洗を図8bに示す，破壊はスチフナーとダイアフラム溶接部の端部 から発生している. 図4a，4fを合わせて示した図7より，鋼管内部 へのコンクリート充填により, 強軸と弱軸の剛性, 変形特性の差 が顕著に小さくなり，等方性的な挙動を示すことが分かる.

（6）鋼管の外径寸法（図4e）：図4eに示す実大サイズの試験体WD850 の挙動は，サイズ増大に伴う耐力の増加を除いて，縮小試験体（た とえば, WD500-tc9，WD500-tc16）と大きく変わるところはな い. 図4の結果からは，これ以上の試験体サイズの影響に関する情 報は得られない，寸法効果の有無については，4章で提案する耐力 式の適用性の中で議論する.

試験体の降伏・破壊状況に関しては，弱軸方向では図8aに示すよう なダイアフラムのせん断降伏が明瞭に観察されており, 強軸方向では 
Shear yielding

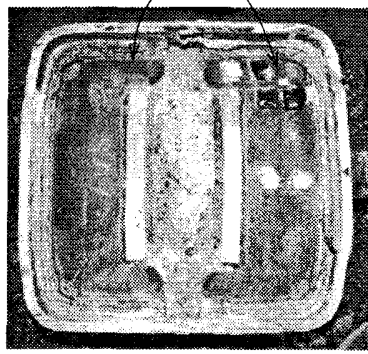

(a) 弱軸方向
Yielding and fracture

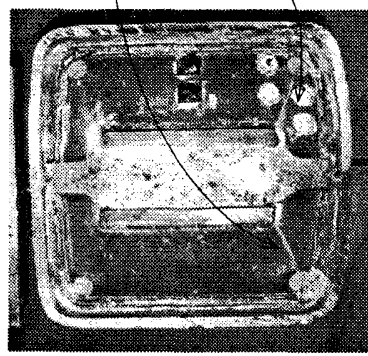

(b) 強軸方向
図8 ダイアフラムの降伏と破壊性状の例

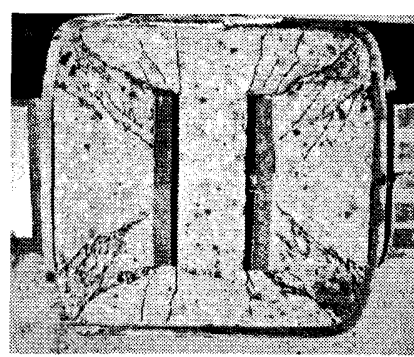

(a) 断面 $\mathrm{A}$

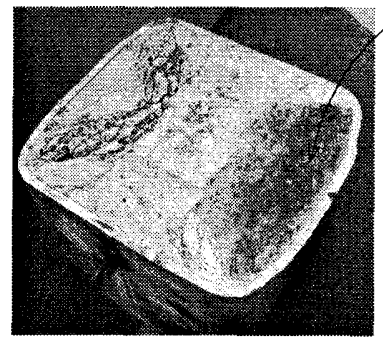

(c) 断面 C

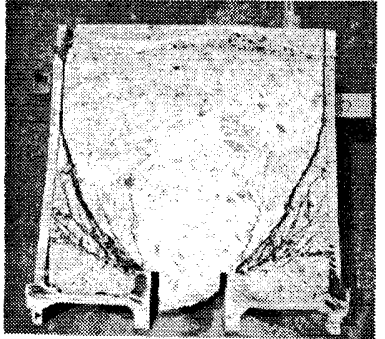

(b) 断面B
Compression failure zone

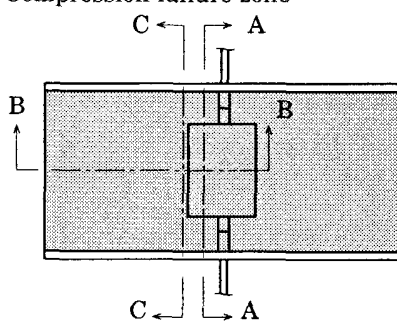

(d) 断面の位置

図9充填コンクリートの破壊状況（弱軸方向試験体）

図8bに見られるような降伏と破壊の両方が発生している，強軸方向試 験体でのダイアフラムの破壊は，荷重-変位関係において初期剛性に 対し十分に剛性が低下した段階で生じており，比較的延性的なもので あったことから，ダイアフラムの降伏が相当範囲まで進展した以降に 発生したものと想定される.なお，弱軸方向では，ダイアフラムが途 切れた区間に位置する鋼管側面に，局所的な塑性化（終局耐力時の歪 み值から判断）がみられた試験体もあったが，亀裂等の破壊現象は観 察されていない，図9は弱軸方向試験体の充填コンクリート部の圧壊, クラック発生状況であり, 試験終了後に試験体を数力所で切断して撮 影したものである. これらの様相から, コンクリートのクラック・圧 壊はダイアフラムに溶接されたスチフナー部分から発生し, 接合部内 で柱断面方向，柱軸方向に進展したことが類推される．結果として， 図9cに見られるように接合部内のコンクリートには3次元的な破壊領 域が形成されている。このようなクラック・圧壊パターンは, T字形 ダイアフラムが充填コンクリート内にアンカーされて抵抗力を発揮し ていることを示すものである. 以上の観察を踏まえて総括すると, 次 のような抵抗機構が存在するものと考えられる. すなわち，(1) 弱軸 方向のCFT接合部の抵抗は，主として鋼管管壁の面外曲げ抵抗，ダイ アフラムのせん断抵抗，T字形ダイアフラムの充填コンクリートへの アンカー効果によりもたらされ，(2) 強軸方向のCFT接合部の抵抗は, 主として鋼管管壁の面外曲げ抵抗とダイアフラムの引張ならびにせん

断抵抗によって発揮される.

\section{CFT接合部の耐カモデルと設計式}

\section{1 基本的な考え方と降伏条件}

3章で明らかになったように, 弱軸と強軸では抵抗機構に明瞭な違 いがあるため, 耐力モデルと設計式については弱軸と強軸で分けて議 論する. 本論文の主眼はコンクリートが充填されたCFT接合部である ため，ここではCFTのケースだけを対象とする．実験を通じて比較的 明膫な降伏・破壊機構が認められるため，まず降伏機構を仮定して耐 力モデルとし，次に上界定理に基づく極限解析技法を適用して基本と なる設計式を導く. 上界定理の適用に当たっては降伏機構の内部仕事 と外部仕事を算出する必要がある. 内部仕事を算出するために, 本論 文では鋼材とコンクリートに対して次のような降伏条件を適用した。 ここで，完全塑性，関連流れ則，微小変形を仮定する.

（1）鋼材：計算が簡便なわりに精度に優れたTrescaの降伏条件を適用

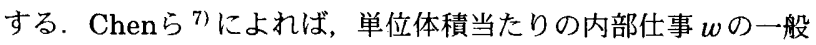
形は次式で与えられる.

$$
w=\sigma_{y} \max |\varepsilon|
$$

ここで, $\quad \max |\varepsilon|$ は与えられた降伏場から定められる絶対值が最 大の主ひずみ（塑性ひずみ）であり， $\sigma_{y}$ は鋼材の降伏強度である. 鋼材に形成される降伏線に適用すると，式1を板厚方向に積分する ことによって, 単位長さ当たりの内部仕事は $M_{p} \theta$ により得られる. ここで， $M_{p}$ は降伏線の単位長さ当たりの全塑性モーメント（= $\left.t^{2} \sigma_{y} / 4\right)$ であり, $\theta$ は降伏線における塑性回転角である.

(2) コンクリート：コシクリートに対してはMohr-Coulombの降伏条 件を適用した。再度Chenら7)を参照すれば，単位体積当たりの 内部仕事 $w$ の一般形は次式で与えられる.

$w=f_{c} \sum\left|\varepsilon^{-}\right|$

ここで， $\Sigma\left|\varepsilon^{-}\right|$は圧縮主ひずみ（塑性ひずみ）の絶対值の総和で あり， $f_{c}$ は極限解析のためのコンクリート強度である. 一般に $f_{\mathrm{c}}$ は，コンクリートのソフトニング挙動のために一軸圧縮強度 $f_{\mathrm{c}}^{\prime}$ よ りも小さくなる. ここではNielsen ${ }^{8)}$ 提案の以下の式を適用した.

$$
f_{c}=\left(0.7-f_{c}^{\prime} / 200\right) f_{c}^{\prime}
$$

ここで, $f_{c}^{\prime}$ の単位は $\mathrm{N} / \mathrm{mm}^{2}$ である

CFT柱に作用する軸圧縮力は安全側として無視する。軸引張が作用す るケースについては実験データが無いため本論文の対象外とする.

4.2 弱軸方向のモデルと耐力式

実験で観察されたモードに基づいて, 梁フランジが変形量 $\boldsymbol{\delta}$ の引張 を受ける場合の降伏機構を図10のように仮定する．提案した降伏機構 は3種類の要素によって構成され，それらは(1) 鋼管面に形成される 降伏線機構（図10a），(2) 充填コンクリートの部分領域が降伏・破壊 する機構（図10b，10c），(3) ダイアフラムがせん断降伏する機構（図 10d）である.ここでは，このような3つの降伏機構の形成によって接 合部が極限状態（塑性流れ）に至るとする.これらの降伏機構は相互 に変形の適合を満足する必要があるため，特に充填コンクリートと鋼 管間の適合性には慎重に配慮してメカニズムを仮定した，図11aには 立体的に描写した充填コンクリートの降伏・破壊領域を示す，なお， 図10，11中の充填コンクリートの降伏・破壊領域は，ダイアフラムの スチフナー幅 $b_{r}$ が梁フランジ幅 $B$ よりも大きなケースに対するもの であり， $b_{r}$ が $B$ よりも小さい場合については本節の後半で議論する. 
基本となる耐力式は，図10の降伏機構に対して極限解析技法を適用 することにより導出するが, 内部仕事の算出が重要なステップとなる. 各々図10a，10bに示した鋼管面の降伏線機構とダイアフラムのせん断 降伏機構については比較的単純であるが, 充填コンクリートの計算は 相当に複雑となる. 充填コンクリートについては, まず図 $11 \mathrm{~b} に$ 示す ように降伏・破壊領域を5種類に分け, 各領域ごとに線形の変位場を 仮定する. つぎに式2を適用して各領域の内部仕事を計算し, 最後に 全ての領域の内部仕事を合算して求める方法をとる. 図11bに示す要 素Dを対象に, その計算過程の概要を以下に示す. 図12は要素D中の ひとつの三角錐領域の变形前後の形状を示したものであり, 節点座標 と変位を定義するための局所座標も示している. 図中に示した 2 本の 矢印は降伏機構が形成された際の節点の変位ベクトルである. 座標 $x$, $y, z$ に対応する変位を各々 $u, v, w$ と定義する. 各々の変位は $x$, $y, \quad z$ の線形関数で表現できるとすると, 図12の変位場は以下のよう に記述できる.

$$
(u, v, w)=\left(\delta-y \delta / Y_{0}-z \delta / X, 0,0\right)
$$

対応するひずみ場は簡単に定義でき, 主ひずみは以下のようになる.

$$
\varepsilon_{1}=-\varepsilon_{3}=(\delta / 2) \sqrt{1 / X^{2}+1 / Y_{0}^{2}}, \quad \varepsilon_{2}=0
$$

式5から分かるように，このひずみ場は平面ひずみ状態である. 式5を 式 2 に代入すると, 要素Dの三角錐領域ひとつがなす内部仕事 $W_{\text {cvn }}^{D}$ は次 のようになる.

$$
W_{\text {con }}^{D}=\left(L_{d} X Y_{0} \delta / 12\right) f_{c} \sqrt{1 / X^{2}+1 / Y_{0}{ }^{2}}
$$

同様に他の要素中の三角錐または三角柱領域の内部仕事も算出するこ とができる.

$$
\begin{aligned}
& W_{c o n}^{A}=\left(L_{d} B \delta / 4\right) f_{r} \\
& W_{r i n}^{B}=\left\{L_{d}\left(h,-t_{d}\right) \delta / 8\right\} f_{r} \\
& W_{c u n}^{C}=\left\{L_{d}\left(h_{r}-t_{d}\right)\left(Y_{0}-Y_{1}\right) \delta /\left(8 Y_{0}\right)\right\} f_{r} \\
& W_{r u n}^{E}=\left\{L_{d} X\left(Y_{0}-Y_{1}\right) \delta / 12\right\} f_{r} \sqrt{1 / X^{2}+1 / Y_{0}^{2}}
\end{aligned}
$$

要素Dと同様, いずれ要素も平面ひずみ状態である. コンクリートの 全内部仕事は，これら内部仕事の総和で算出することができる。

図10aに示す鋼管面上の降伏線メカニズムと図10dのダイアフラムの せん断降伏に起因する内部仕事を算出して, 全内部仕事と外部仕事を 等值すると, 以下の耐力評価式が得られる。なお, ダイアフラムにつ いては図13に示すように形状を単純化している.

$$
\begin{aligned}
& P_{y 0}=P_{y}^{d}+P_{y}^{t}+P_{y}{ }^{\prime} \\
& P_{y}{ }^{d}=\sigma_{y}^{d}\left\{L_{d} Y_{0}-\pi(d / 2)^{2}\right\} t_{d} / Y_{0} \\
& P_{y}{ }^{t}=4 M_{n}^{t}\left\{(2 Y+B) / X+\left(2 X+h_{r}\right) / Y\right\} \\
& P_{y}{ }^{r}=f_{c} L_{d d}\left\{\left(h_{r}-t_{d}\right)\left(2-Y_{1} / Y_{0}\right) / 2\right. \\
& \left.+B / 2+\sqrt{X^{2}+Y_{0}^{2}}\left(2-Y_{1} / Y_{0}\right) / 3\right\}
\end{aligned}
$$

ここで、 $P_{y}{ }^{d}, P_{y}{ }^{t}, P_{y}{ }^{\prime}$ は, 各々ダイアフラムのせん断降伏. 鋼管面 の降伏線メカニズム, 内部コンクリートの降伏・破壊による抵抗值を 示す. $P_{y}{ }^{d}$ については曲げ降伏により支配されるケースもあり得るが, 実験では全てせ九断降伏で決定されていたため, 式12での算出は実用 上妥当であると評価している. ただし, 特殊な形状や寸法のダイアフ ラムなどでは曲げ降伏の可能性もあるため, その場合には, 文献9を 参考として $P_{y}{ }^{d}$ を評価する. 式13の $M_{p}^{t}$ は鋼管スキンプレートの単位 幅当たりの全塑性曲け耐力であり, $M_{p}^{t}=t_{c}^{2} \sigma_{y}^{t} / 4$ で与えられる. $\sigma_{y}^{d}$, $\sigma_{y}^{\prime}$ は鋼管とダイアフラム・ウエブ部の降伏強度である. 直径 $d$ の空気 抜き孔については, せん断抵抗面積から欠損面積を除くことにより考 慮する. なお, ダイアフラムに溶接されるリブについてはアンカーカ
Yield line on steel tube

Failure (yield) zone of concrete

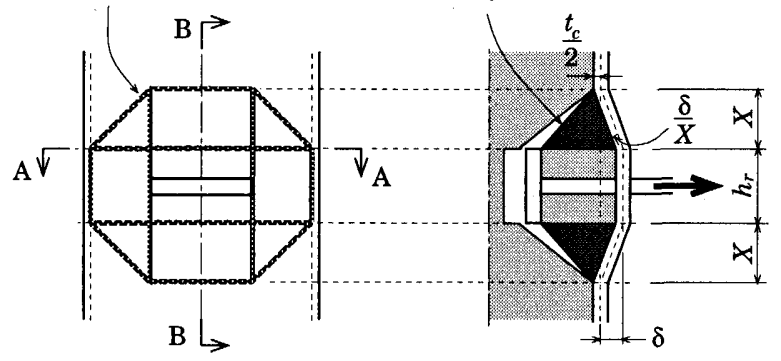

(a) 鋼管に形成される降伏線

(b) 断面B

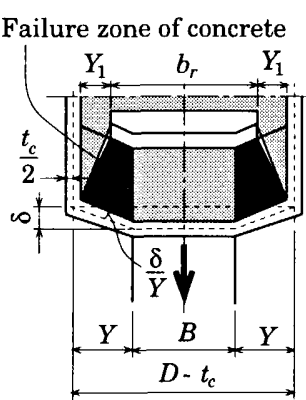

(c) 断面 $\mathrm{A}$
Shear yielding zone

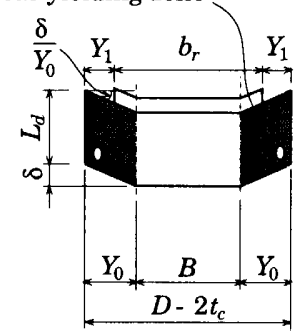

(d) ダイアフラムのせん断降伏

図10 仮定した降伏機構（弱軸方向）

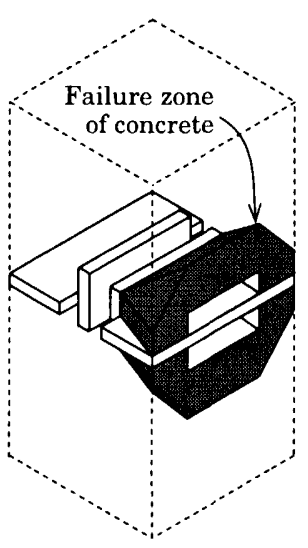

(a) 降伏・破壊領域

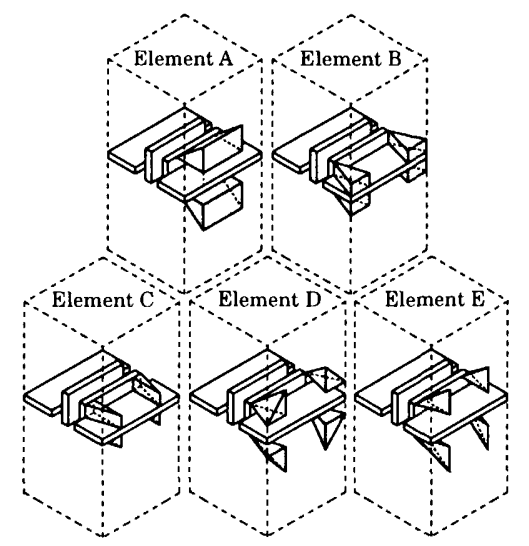

(b) 分割した降伏・破壊領域
図11 仮定したコンクリートの降伏・破壊領域（弱軸方向）

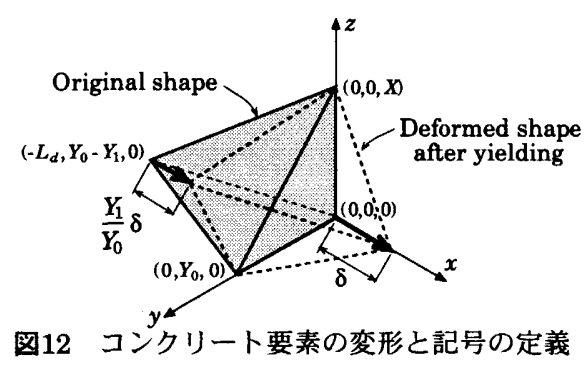

により降伏しないように厚みを決定する必要がある.

式13，14中の距離 $X$ は鋼管面の降伏メカニズムの管軸方向の幅を示 すものであり，未定な変数である. $X$ は上界定理により $P_{y_{0}}$ を最小化 するように決定できる，得られた $X$ は陽な形で表記できないが, 次式 を満足するように繰り返し計算により与えられる.

$$
\begin{aligned}
4 M_{p}^{t}\left\{-(2 Y+B) / X^{2}+2 / Y\right\}+ \\
f_{c} L_{d} X\left(2-Y_{1} / Y_{0}\right) /\left(3 \sqrt{X^{2}+Y_{0}^{2}}\right)=0
\end{aligned}
$$


既に述べたように，式11〜15はダイアフラムのスチフナの幅 $b_{r}{ }_{r}$ が梁 フランジ幅 $\boldsymbol{B}$ よりも大きいケースが対象となる．この範囲外の場合に は，内部コンクリートの降伏・破壊領域の修正が必要となる．図14に $b r$ と $B$ の大小関係の違いによる降伏・破壊領域の相違を示す．図 $14 \mathrm{~b}$ のケースに対しては，式14と15の代わりに各々式16，17を適用する.

$$
\begin{aligned}
P_{y}^{c}=f_{\mathrm{c}} & \left\{\left\{L_{d}-\left(Y_{1}-Y_{0}\right)\left(h_{r}-t_{d}\right) / 2\right\}+L_{d} b_{r} / 2\right. \\
& +\left(L_{d} / 3\right)\left\{\sqrt{\left\{1+\left(Y_{1}-Y_{0}\right)^{2} / L_{d}{ }^{2}\right\} X^{2}+Y_{0}{ }^{2}}\right. \\
& \left.-\left(Y_{1}-Y_{0}\right) X / L_{d}+2\left(Y_{1}-Y_{0}\right)\right\} \\
4 M_{p}^{t}\{ & \left.-(2 Y+B) / X^{2}+2 / Y\right\} \\
+ & \left\{\left\{1+\left(Y_{1}-Y_{0}\right)^{2} / L_{d}{ }^{2}\right\} X /\left\{\sqrt{\left\{1+\left(Y_{1}-Y_{0}\right)^{2} / L_{d}{ }^{2}\right\} X^{2}+Y_{0}{ }^{2}}\right\}\right. \\
& \left.-\left(Y_{1}-Y_{0}\right) / L_{d}\right\}\left(f_{\mathrm{c}} L_{d} / 3\right)=0
\end{aligned}
$$

表4に実験結果と上記式に基づく計算結果の比較を示す．表中の試 験体SD500は後述する強軸方向の結果であるため,ここでの議論では 対象外とする. 此較から分かるように, 提案された評価式の結果は, 降伏耐力については大きめの結果を与え, 終局耐力についてはかなり 小さな耐力を与える. これらの傾向は, 耐力式の導出において, 材料 は完全剛塑性体であると仮定していることに起因する. 図15の模式図 に示すように，現実にはダイアフラム，鋼管，コンクリートのいずれ の抵抗要素共に弾塑性挙動を示し, 加えて降伏以降の性状は抵抗要素 によって大きく異なる. また, 図15に示されるように, 変形の大きさ によって各抵抗要素間の分担率が変化する. この結果, 降伏耐力と終 局耐力の各々のレベルにおいて, 抵抗要素間の荷重分担順位に違いが 生ずる.このような極限解析での仮定と実体の違いを考慮すると, 何 らかの耐力式の補正が必要となることが分かる。

本論文では式11を基本としながら, 耐力式の各項に補正係数を乗ず ることにより，降伏耐力と終局耐力に対して別々の耐力式を提案する.

$$
\begin{aligned}
& P_{y d}=\alpha_{y}^{d} P_{y}^{d}+\alpha_{y}^{t} P_{y}^{t}+\alpha_{y}^{c} P_{y}^{c} \\
& P_{u d}=\alpha_{u}^{d} P_{u}^{d}+\alpha_{u}^{t} P_{u}^{t}+\alpha_{u}^{c} P_{y}^{c}
\end{aligned}
$$

ここで, $P_{y d}$ と $P_{u d}$ は, 各々降优耐力之終局耐力の予測值であり, $\alpha_{y}^{d}$, $\alpha_{y}^{t}, \quad \alpha_{y}^{c}$ は降伏耐力式での補正係数である. 一方, $\alpha_{u}^{d}, \alpha_{u}^{t}, \alpha_{u}^{c}$ は終 局耐力式での各項の補正係数である. $P_{y}^{d}, P_{y}^{t}, P_{y}^{\mathrm{c}}$ は, 式12, 13, 14, 16式で与えられるダイアフラム, 鋼管, コンクリートの降伏耐力 成分である. $P_{u}^{d}$ と $P_{u}{ }^{t}$ はダイアフラムと鋼管の終局耐力成分であり, 式 12,13 に鋼材の降伏強度 $\sigma_{y}$ の代わりに引張強度 $\sigma_{u}$ を適用して求め る. 終局耐カレベルでは, 鋼材は既に加工硬化域に到達していること を考虑して，便宜上 $\sigma_{y}$ の代わりに $\sigma_{u}$ を適用するとした. コンクリー

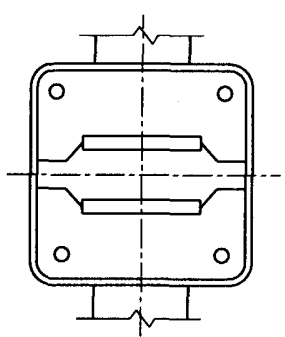

(a) 実形状

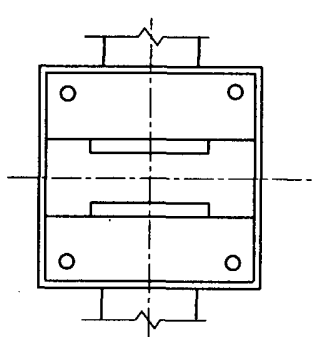

(b) 単純化した形状
図13 ダイアフラム形状の単純化

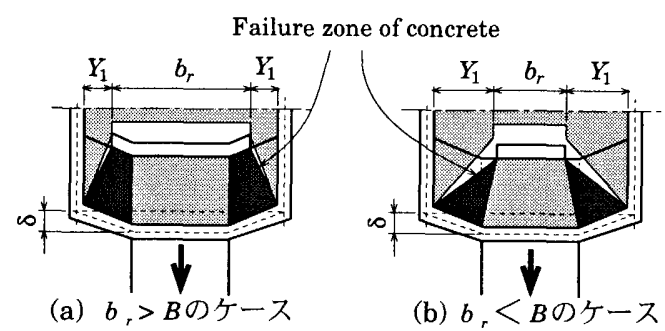

図14 ダイアフラム形状の単純化

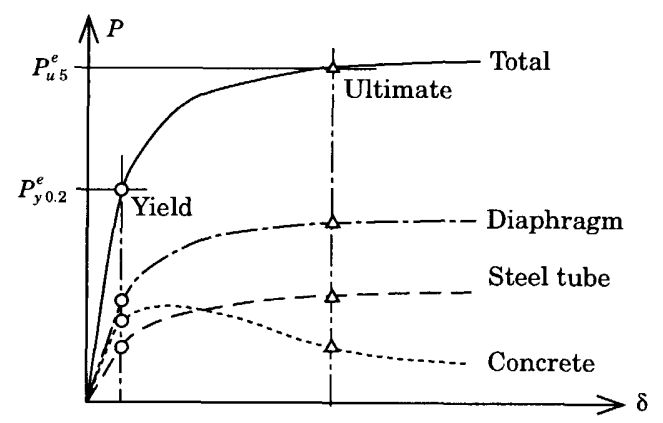

図15 抵抗要素間の抵抗特性の違い

トについては，図15の模式図から分かるように加工硬化特性を示さな いため, 終局耐力式（式19）でも降伏耐力式（式18）と同じ $P_{y}^{c}$ を適

\begin{tabular}{|c|c|c|c|c|c|c|c|c|}
\hline \multirow{3}{*}{ Name } & \multicolumn{2}{|c|}{ Test result } & \multicolumn{4}{|c|}{ Calculated strength } & \multirow{2}{*}{\multicolumn{2}{|c|}{$\begin{array}{l}\text { Test result to calculated } \\
\text { strength ratio }\end{array}$}} \\
\hline & \multirow{2}{*}{\begin{tabular}{|c|} 
Yield strength \\
$P_{\text {y }}^{\mathrm{e}}$ \\
$(\mathrm{kN})$ \\
\end{tabular}} & \multirow{2}{*}{$\begin{array}{c}\text { Ultimate strength } \\
P_{u 5}^{e} \\
(\mathrm{kN}) \\
\end{array}$} & \multirow{2}{*}{$\begin{array}{c}\text { Steel tube } \\
P_{y}^{t} \\
(\mathrm{kN}) \\
\end{array}$} & \multirow{2}{*}{$\begin{array}{c}\text { Diaphragm } \\
P_{y}^{d} \\
(\mathrm{kN}) \\
\end{array}$} & \multirow{2}{*}{$\begin{array}{c}\text { Concrete } \\
P_{y}^{c} \\
(\mathrm{kN}) \\
\end{array}$} & \multirow{2}{*}{$\begin{array}{c}\text { Total } \\
P_{y 0} \\
(\mathrm{kN}) \\
\end{array}$} & & \\
\hline & & & & & & & $\begin{array}{l}\text { Yield } \\
\text { strength }\end{array}$ & $\begin{array}{l}\text { Ultimate } \\
\text { strength }\end{array}$ \\
\hline WD500-tc16 & \begin{tabular}{|l|}
2032 \\
\end{tabular} & \begin{tabular}{|l|}
3079 \\
\end{tabular} & 624 & 848 & 731 & 2203 & 0.92 & 1.40 \\
\hline WD500-tc25 & 2460 & 4147 & 1460 & 788 & 682 & 2929 & 0.84 & 1.42 \\
\hline WD500-tc9 & 1815 & 2501 & 228 & 919 & 809 & 1956 & 0.93 & 1.28 \\
\hline WD500-hr140 & 2049 & 3268 & 654 & 851 & 833 & 2339 & 0.88 & 1.40 \\
\hline WD500-hr60 & 1872 & 2924 & 593 & 849 & 681 & 2123 & 0.88 & 1.38 \\
\hline WD500-hr0 & 1256 & 2513 & 558 & 987 & 0 & 1545 & 0.81 & 1.63 \\
\hline WD500-br335 & 2040 & 3203 & 631 & 847 & 849 & 2327 & 0.88 & 1.38 \\
\hline WD500-br150 & 1737 & 2744 & 618 & 842 & 589 & 2049 & 0.85 & 1.34 \\
\hline WD500C-35 & 2036 & 3051 & 598 & 855 & 759 & 2212 & 0.92 & 1.38 \\
\hline WD500C-20 & 1792 & 2881 & 590 & 852 & 485 & 1926 & 0.93 & 1.50 \\
\hline WD500C-60 & 2068 & 3246 & 602 & 850 & 906 & 2359 & 0.88 & 1.38 \\
\hline WD850 & 4788 & 7186 & 1140 & 2169 & 2384 & 5693 & 0.84 & 1.26 \\
\hline SD500 & 1801 & 3010 & 559 & 1546 & 0 & 2105 & 0.86 & 1.43 \\
\hline
\end{tabular}
用した. 実験結果（降优耐力は $P_{y 0.2}^{e}$, 終局耐力は $P_{u 5}^{e}$ とした）に基 づいて, 式18，19を基本とした重回帰分析を行うと，次のように補 正係数が与えられる.

$$
\begin{aligned}
& \alpha_{y}^{d}=0.91, \alpha_{y}^{t}=0.82, \quad \alpha_{y}^{c}=0.84 \\
& \alpha_{u}^{d}=1.35, \alpha_{u}^{t}=1.04, \quad \alpha_{u}^{c}=0.42
\end{aligned}
$$

表4 実験結果と計算結果の比較 
表5 降伏耐力式の精度

\begin{tabular}{l|c|c|c|c|c|c}
\hline \multirow{2}{*}{ Name } & \multirow{2}{*}{$\begin{array}{c}\text { Test } \\
\text { result }\end{array}$} & \multicolumn{4}{|c|}{ Calculated strength } & $\begin{array}{c}\text { Test to } \\
\text { calculated } \\
\text { ratio }\end{array}$ \\
\cline { 3 - 8 } & $\begin{array}{c}P_{y 0.2}^{e} \\
(\mathrm{kN})\end{array}$ & $\begin{array}{c}\alpha_{y}^{t} P_{y}^{t} \\
(\mathrm{kN})\end{array}$ & $\begin{array}{c}\alpha_{y}^{d} P_{y}^{d} \\
(\mathrm{kN})\end{array}$ & $\begin{array}{c}\alpha_{y}^{c} P_{y}^{c} \\
(\mathrm{kN})\end{array}$ & $\begin{array}{c}P_{y d} \\
(\mathrm{kN})\end{array}$ & \\
\hline WD500-tc16 & 2032 & 511 & 771 & 614 & 1897 & 1.07 \\
\hline WD500-tc25 & 2460 & 1197 & 717 & 573 & 2486 & 0.99 \\
\hline WD500-tc9 & 1815 & 187 & 836 & 679 & 1702 & 1.07 \\
\hline WD500-hr140 & 2049 & 537 & 775 & 700 & 2011 & 1.02 \\
\hline WD500-hr60 & 1872 & 486 & 773 & 572 & 1831 & 1.02 \\
\hline WD500-hr0 & 1256 & 457 & 898 & 0 & 1356 & 0.93 \\
\hline WD500-br335 & 2040 & 517 & 771 & 713 & 2001 & 1.02 \\
\hline WD500-br150 & 1737 & 507 & 766 & 495 & 1768 & 0.98 \\
\hline WD500C-35 & 2036 & 491 & 778 & 638 & 1906 & 1.07 \\
\hline WD500C-20 & 1792 & 484 & 775 & 407 & 1666 & 1.08 \\
\hline WD500C-60 & 2068 & 494 & 774 & 761 & 2029 & 1.02 \\
\hline WD850 & 4788 & 934 & 1974 & 2003 & 4911 & 0.98 \\
\hline SD500 & 1801 & 475 & 1314 & 0 & 1789 & 1.01 \\
\hline
\end{tabular}

これらの補正係数を適用して, 式18と19式で各々降伏耐力と終局耐力 を評価すると，表 5 と6に示されるように比較的高い精度を与えること が分かる. 計算値に対する実験值の比の平均值と変動俰数 (COV) は, 降伏耐力に対して各々 $1.02 ， 0.045$ あ゙あ，終局耐力に対しては各々 1.01，0.035であった. なお，式 21 中の $\alpha_{u}^{d}$ の值が1を大きく越えてい る点に注意が必要である. $\alpha_{u}^{d}$ を乗じている $P_{u}^{d}$ は $\sigma_{u}$ を使って計算して いるため， $\alpha$ dは1以下となるのが普通である，安全側の評価を与える Trescaの降伏条件を適用していること, ダイアフラムの現実の降伏状 態は純せん断降伏では無いことなどが起因しているものと想定される.

表5と6に示す提案式の精度から，前章で省略された寸法効果につい て考察を加えることができる．表中の実大試験体WD850に注目すると， 他の縮小試験体と比較して評価精度に関して大きな相違は見られない. このことは, 今回の試験の範囲では特段の寸法効果は現れていないこ とを意味する

\section{3 強軸方向のモデと耐力式}

前章で述べたように, 強軸方向の特性については充填コンクリート の強い影暜は観察されていない. そこで, 強軸方向の耐力モデルを考 える上では，安全側としてコンクリートの存在を無視する．弱軸と同 様な技法で強軸の耐力式を導くこととする．弱軸と同様に，まず図16 に示すようにダイアフラムの形状を単純化する．実験観察から明らか なように，強軸では二つの降伏モードを仮定する．図17に示すように， 一つは鋼管面での降伏線メカニズムであり，一方はダイアフラムの局 部的な降伏（引張・せん断降状）モードである. 図17aの降伏線メ力 ニズムは弱軸と比較的類似したモードであり，ダイアフラムの局部降 伏モードは図17b中のグレーにハッチングされた領域が降伏するモー ドである. 弱軸の充填コンクリートの内部仕事の評価と同様に, 図 $17 \mathrm{~b}$ のように，降伏領域をGとFの二つの要素に分けて内部仕事を評価す る. 以下にダイアフラム降伏モードの内部仕事の評価過程をFの要素 について示す（図18）. 座標 $x$ と $y$ 方向の変位を各々 $u$ と $v$ とし 座標の一次関数で変位場を記述すると次のようになる.

$$
(u, v)=\left(0,\left(\delta / Y_{3}\right)\left(-x+L_{d} y / L_{2}\right)\right)
$$

記号については図17を参照されたい。この変位場の主ひずみは,

$$
\varepsilon_{1}, \varepsilon_{3}=\left(\delta / 2 Y_{3}\right)\left(L_{d} / L_{2} \pm \sqrt{\left(L_{d} / L_{2}\right)^{2}+1}\right)
$$

となる。式1を適用すると要素Fの内部仕事 $W_{F}$ は,

$$
W_{F}=(\delta / 4)\left(L_{d}+\sqrt{L_{d}{ }^{2}+L_{2}{ }^{2}}\right) t_{d} \sigma_{y}^{d}
$$

となる. 同様に, 要素Gの内部仕事は次式で与えられる.
表6 終局耐力式の精度

\begin{tabular}{l|c|c|c|c|c|c}
\hline \multirow{2}{*}{ Name } & $\begin{array}{c}\text { Test } \\
\text { result }\end{array}$ & \multicolumn{4}{|c|}{ Calculated strength } & $\begin{array}{c}\text { Test to } \\
\text { calculated } \\
\text { ratio }\end{array}$ \\
\cline { 3 - 8 } & $\begin{array}{c}P_{u 5}^{e} \\
(\mathrm{kN})\end{array}$ & $\begin{array}{c}\alpha_{u}^{t} P_{u}^{t} \\
(\mathrm{kN})\end{array}$ & $\begin{array}{c}\alpha_{u}^{d} P_{u}^{d} \\
(\mathrm{kN})\end{array}$ & $\begin{array}{c}\alpha_{u}^{c} P_{u}^{c} \\
(\mathrm{kN})\end{array}$ & $\begin{array}{c}P_{u d} \\
(\mathrm{kN})\end{array}$ & \\
\hline WD500-tc16 & 3079 & 960 & 1746 & 307 & 3014 & 1.02 \\
\hline WD500-tc25 & 4147 & 2297 & 1622 & 286 & 4206 & 0.99 \\
\hline WD500-tc9 & 2501 & 342 & 1892 & 340 & 2574 & 0.97 \\
\hline WD500-hr140 & 3268 & 1008 & 1753 & 350 & 3111 & 1.05 \\
\hline WD500-hr60 & 2924 & 913 & 1750 & 286 & 2948 & 0.99 \\
\hline WD500-hr0 & 2513 & 730 & 1728 & 0 & 2458 & 1.02 \\
\hline WD500-br335 & 3203 & 971 & 1745 & 357 & 3073 & 1.04 \\
\hline WD500-br150 & 2744 & 951 & 1734 & 248 & 2933 & 0.94 \\
\hline WD500C-35 & 3051 & 930 & 1759 & 319 & 3008 & 1.01 \\
\hline WD500C-20 & 2881 & 916 & 1754 & 204 & 2874 & 1.00 \\
\hline WD500C-60 & 3246 & 936 & 1750 & 381 & 3067 & 1.06 \\
\hline WD850 & 7186 & 1852 & 4404 & 1001 & 7258 & 0.99 \\
\hline SD500 & 3010 & 787 & 2241 & 0 & 3028 & 0.99 \\
\hline
\end{tabular}

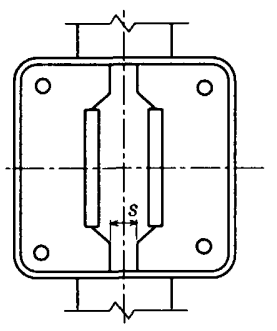

(a) 実際の形状

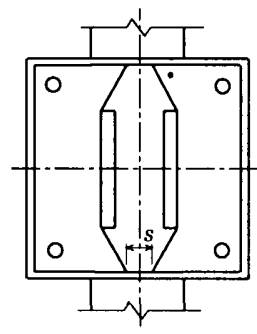

(b) 単純化した形状
図16 強軸方向のダイアフラム形状の単純化

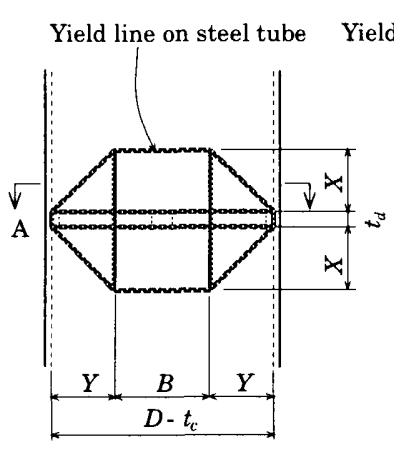

（a）鋼管面での降伏線

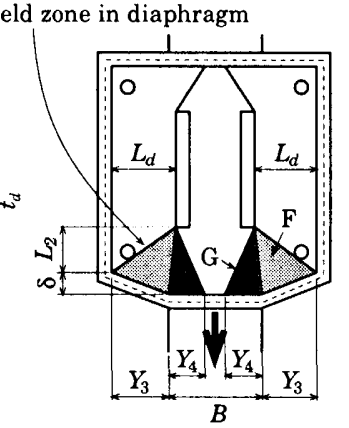

(b) ダイアフラム降伏
図17強軸方向の降伏メカニズム

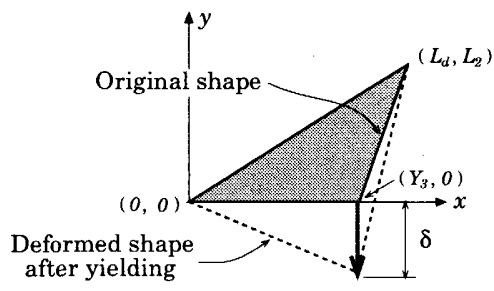

図18 降伏後のひずみ場

$$
W_{G}=\delta \quad Y_{4} t_{d} \sigma_{y}^{d} / 2
$$

図17aの降伏線メカニズムの内部仕事を算出し, 全内部仕事と外部仕 事を等置して，上界定理を適用すると次式が得られる.

$$
\begin{aligned}
& P_{y 0}=P_{y}{ }^{d}+P_{y}{ }^{t} \\
& P_{y}{ }^{d}=\left\{\left(L_{d}+\sqrt{L_{d}{ }^{2}+L_{2}{ }^{2}}\right) / 2+Y_{4}\right\} t_{d} \sigma_{y}{ }^{d} \\
& P_{y}{ }^{t}=4 M_{p}{ }_{p}\left\{(2 Y+B) / X+\left(2 X+t_{d}\right) / Y\right\} \\
& X=\sqrt{Y(2 Y+B) / 2}
\end{aligned}
$$


唯一の強軸のCFT 試験体SD500について, 実験結果之計算結果の 比較を表4に示す，弱軸でも見られたように，その評価精度は余り良 くない. そこで弱軸と同様に式26の各項に補正俰数を考慮して, 降伏 耐力と終局耐力の二つの耐力式を提案する。

$$
\begin{aligned}
& P_{y d}=\alpha_{y}^{d} P_{y}{ }^{d}+\alpha_{y}^{t} P_{y}{ }^{t} \\
& P_{u d}=\alpha_{u}^{d} P_{u}{ }^{d}+\alpha_{u}^{t} P_{u}{ }^{t}
\end{aligned}
$$

ここで， $P_{y d}$ と $P_{u d}$ は，各々降伏耐力と終局耐力の予測值であり， $\alpha_{y}^{d}$ と $\alpha_{y}^{t}$ は降伏耐力式での補正保数である. 一方， $\alpha_{u}^{d}$ と $\alpha_{u}^{t}$ は終局耐力 式での各項の補正係数である． $P_{y}^{d}$ と $P_{y}^{t}$ は，式27，28式で与えられる ダイアフラム, 鋼管の降伏耐力成分である. $P_{u}^{d}$ と $P_{u}{ }^{\dagger}$ はダイアフラム と鋼管の終局耐力成分であり，式 $27 ， 28$ に鋼材の降伏強度 $\sigma_{y}$ に代え て引張強度 $\sigma_{u}$ を適用して求める. 強軸方向のCFT試験体は一体だけで あるため, 弱軸と同様な重回帰分析により式30，31の補正係数を定め ることはできない，そこで本論文では， $\alpha_{y}^{d}=\alpha_{y}^{t} ， \quad \alpha_{u}^{d}=\alpha_{u}^{t}$ を仮定する と共に，実験結果と式30，31を照らし合わせて，

$$
\alpha_{y}^{d}=\alpha_{y}^{t}=0.85, \quad \alpha_{u}^{d}=\alpha_{u}^{t}=0.95
$$

と補正係数を定めた．表5，6の試験体SD500に対して，式30，31の耐 力式の精度を示す，一体の試験結果から逆算で求めているため, 当然 高い精度を示す結果となっている. 当然であるが，式 $32 ， 33$ の補正係 数については，今後のデー夕蓄積に基づく更なる検討が必要である.

\section{5. まとめ}

二組のT字形ダイアフラム（スプリットダイアフラム形式）で内部 補強されたCFT角形鋼管柱・梁接合部の仕口強度について, 単純引張 試験に基づいて調査を行った．実験観察に基づいて降伏・破壊モード と抵抗モデルを明らかにすると共に，極限解析の技法により耐力評価 式を導いた。得られた知見をまとめると以下のようになる.

（1）鋼管柱内部へのコンクリート充填（CFT化）は，特に弱軸方向接 合部の剛性と耐力を顕著に増大する効果をもたらし, 結果として強 軸と弱軸の力学特性の差を小さくする. 弱軸と強軸の挙動差が著し い非CFTの接合部（純Sの接合部）と比較すると，コンクリート充 填は接合部の挙動を等方性化する効果を持つ.

(2) 弱軸方向におけるコンクリート充填の効果は, 主としてT字形ダイ アフラムのコンクリートへのアンカー効果に起因する. 鋼管の板厚, ダイアフラムのリブの寸法, コンクリート強度も接合部の強度と剛 性に影響をおよぼす，実験観察より，弱軸方向では三つの抵抗要素 の存在が確認された。それらは，1）鋼管スキンプレートの面外抵 抗，2）T字形ダイアフラムのコンクリートへのアンカー抵抗，そし て3) ダイアフラムそのもののせん断抵抗である.

(3) 強軸方向特性については, 充填コンクリートは剛性と耐力を若干 向上する効果を持つが，強軸と比較するとその程度は小さい，強軸 方向では二つの抵抗要素の存在が認められた. 一つは鋼管スキンプ レートの面外抵抗であり, 他方はダイアフラムの面内の引張・せん 断抵抗である.

(4) 観察された実験結果に基づいて, 弱軸・強軸両方向に対する耐力 モデルを提案した. 加えて, 極限解析技法により耐力評価式 (降伏 耐力，終局耐力）を導いた，実験結果との比較を通じて，提案式は 高い精度を持つことが示された，強軸耐力式については，基本とし た実験データが少ないため，更なるデータ蓄積が必要である. なお，逆対称荷重や非対称荷重を受ける際の接合部の応力状態の調
査, 梁フランジ端部の処理が梁端部の破断現象に与える影響, 柱軸力 が接合部局部の力学挙動に与える影響など, 本研究の範囲で検討でき ていない事項は, 今後の課題である。

\section{参考文献}

1）福元敏之 : コンクリート充填鋼管構造柱はり接合部の研究開発, コンクリー 卜工学, Vol.38, No.10, pp.3-9, 2000年10月

2）独立法人建築研究所監修: 突き合わせ継手の食い違い仕口のずれの検査 補強マニュアル，鉄骨製作管理技術者登録機構，p.312，2003年

3）横山 泉, 笹治 峻, 橋田 浩, 香田伸次 : 角形CFT柱の赛大施工実験 その1 3, 日本建筑学会大会学術講演梗概集A-1分冊, pp.499-504, 1999年

4）柳尚孝, 鈴木孝彦, 山口種美, 鈴木健二, 高田信宏 : スプリットダイア フラムを有するCFT柱梁接合部の耐力, 日本建築学会大会学術講演梗概集 構造III, pp.979-980，1996年

5）佐々木聡，寺岡 勝，森田耕治：簡易内部補強形式コンクリート充填鋼管 柱・鉄骨梁接合部の力学挙動に関する実験的研究, 日本建筑学会大会学術講 演梗概集 構造II，pp.1527-1528，1994年

6）坂田弘安，笠井和彦，伊茂治 聡介：CFT柱に埋め込まれたアンカーボル 卜の引き抜き挙動に関する実験的研究 その 1 2, 日本建築学会大会学術講 演梗概集C-1分冊，pp.1213-1216，2000年

7) Chen, W.F. and Han, D.J. : Plasticity for structural engineers, Springer-Verlag, p.606, 1988

8) Nielsen, M.P.: Limit analysis and concrete plasticity, Second edition, CRC Press, p.908, 1998

9）清水信孝, 藤岡 厷, 島崎尚武, 菅野良一, 鈴木孝彦, 志村保美 : スプリッ トダイアフラム補強された角形龬管柱はり接合部の局部耐力に関する研究 その2 局部耐力式の提案, 日本建築学会大会学術講演梗概集, C-1分冊, pp.723-724, 2002年

10）森田耕次, 横山幸夫, 川又康博, 松村弘道: コンクリート充てん角形鋼管 柱一鉄骨はり接合部の内ダイアフラム補強に関する研究, 日本建築学会構造 系論文報告集，第422号，pp.65-96、1991年4月

(2004年12月27日原稿受理，2005年 7 月 5 日採用決定） 